\title{
TRADE NEWS
}

Please send trade news information and illustrations to Terry M ordecai at the BDJ, 64 Wimpole Street, London W1G 8YS. Trade news is supplied as a service to the reader and does not imply endorsement by the BDJ. Normal and prudent research should be exercised before purchase or use of any product mentioned.

\section{Prestige trade online}

Leading dental supplier and service provider, Prestige Dental, is launching a new surgery catalogue which will be available to dentists as either a CD ROM, online or a traditional paper based format.

The new catalogue covers a host of areas including; hand instruments, small equipment from Parkell, impression trays and materials, oral hygiene, rotary instruments, TMJ/occlusion.

Each sector incorporates a clear explanation of the product area; benefits and clinical applications and includes brands from the leading manufacturers that Prestige represents in the UK. For a copy of the catalogue phone 0800591175 or visit www.prestige- dental.co.uk.

Reader response number 52

\section{Coltenes new push}

Coltene Whaledent is pleased to announce the new UC50D ultrasonic cleaner with a push button timer. Coltene Whaledent claims the cleaner provides a more easy and reliable electronic operation and features illuminated indication of the cleaning cycle.

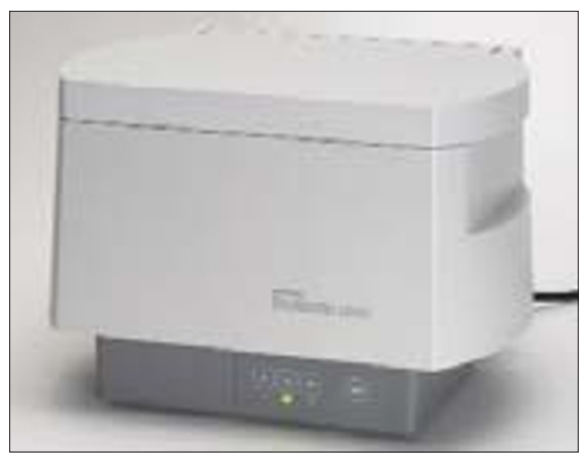

The new FingerGuard plastic basket with a metal bottom reputedly provides superior wave transmission - preventing dulling of instruments. The cover can be fully closed during operation to minimise noise and prevent the escape of airborne contaminants. For more information freephone Coltene Whaledent on 0500295454.

Reader response number 53

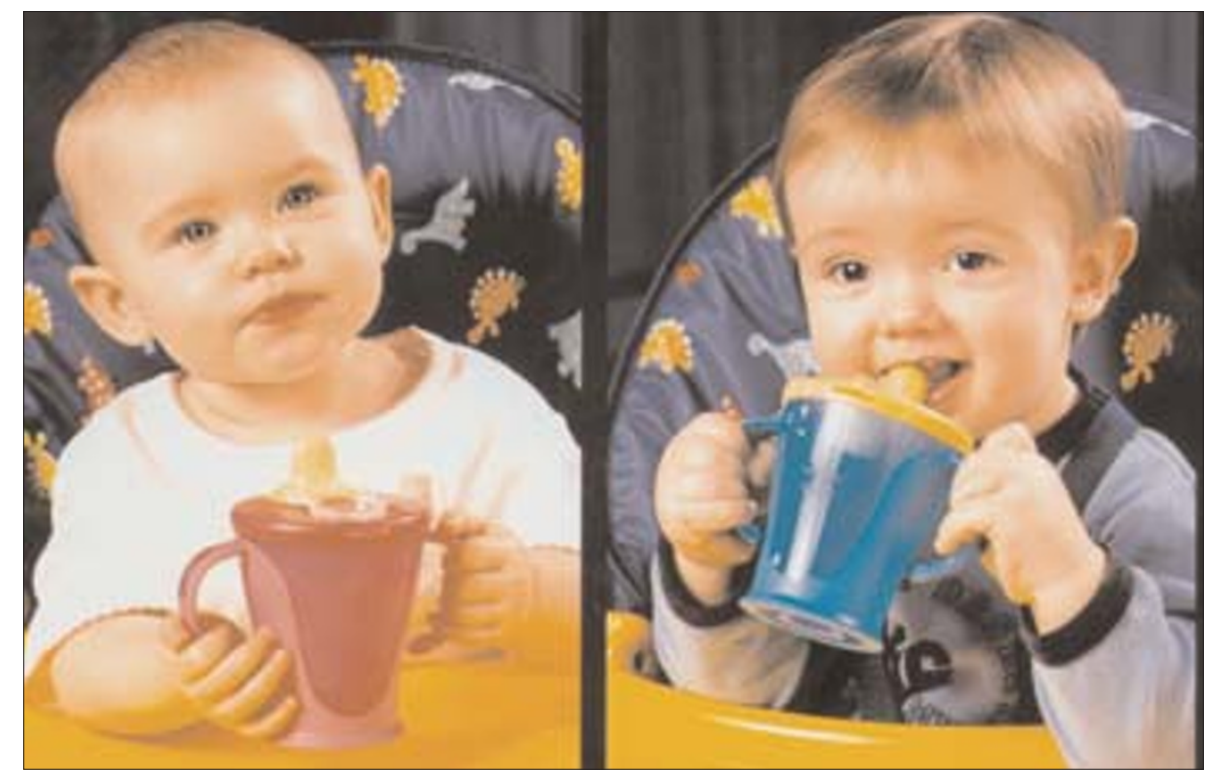

\section{Babies can now go with the Easiflow}

Moving a baby from a bottle to a cup is an important part of a babys development. So for this reason Jackel have created the Tommee Tippee Easiflow.

Designed to be easy to drink from without excessive sucking, Jackel claims the cup offers a wide range of benefits including; an easy- to- peel off lid, spill proof, unique natural action spout to allow the child to control the flow, soft grip easy- to-hold handles and hygiene cover which recesses into the lid when the cup is being used.

The Tommee Tippee Easiflow cup has a soft spout, which uses a natural action like the stripping action used in breast- feeding, to release liquid. The child puts pressure on the spout to get a drink and the moment the pressure is released, the spout seals.

The Tommee Tippee Easiflow cup holds $250 \mathrm{ml}$, but a taller beaker is available with a capacity of $350 \mathrm{ml}$ and has no handles. For more information phone 0500979899. Reader response number 51

\section{The toothpaste straight from Beverly Hills!}

Tooth sensitivity is suffered by as many as one in four adults who feel pain as a result of the sensory nerves reacting to various stimuli. To help combat this Purity Laboratories has created the Beverly Hills Formula toothpaste.

Purity Laboratories claims Beverly Hills Formula is a gentle whitening toothpaste which contains a combination of anti bacterial agents and low abrasion and antistain polishers. The toothpaste contains fluoride and the anticaries agent xylitol.

For more information phone 0208563 8887.

Reader response number 54

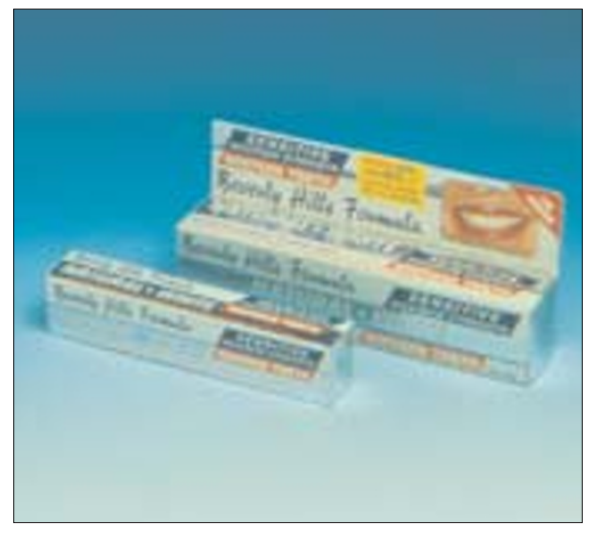

